Boglárka Koller

\title{
BOOK REVIEW: THE EUROPEAN POLIS BY GEORGE SCHÖPFLIN ${ }^{1}$
}

Boglárka Koller, PhD habil, Full Professor, Head of the Department of European Studies, University of Public Service, Faculty of Public Governance and International Studies, koller.boglarka@uni-nke.hu

George Schöpflin's latest monograph provides a unique understanding of the politics of contemporary Europe in two 'interconnected essays'. The first part focuses on a comprehensive interpretation of the EU's political community, the European polis. The author argues that political innovation has slowed considerably in the last decade, particularly after the Lisbon Treaty entered into force and the EU was gradually transformed into a punitive polis. The second part of the book focuses on the relationship between Central Europe and the European Union. Central Europe is European, but differently European. The shortcomings of the Eastern enlargement, Central Europe's misadventure in the European Union and the unseen and unintended consequences of the 2004-2007-2011 enlargement waves all contributed to the development of a troubled relationship between the EU and its new members. The volume combines both theoretical and practical aspects, making it a relevant contribution to European Studies literature.

KeYWORDS:

European Union, Central Europe, political community, punitive polis, rule of law

George Schöpflin, The European Polis (Budapest: Ludovika University Press, 2021). 
This monograph provides specific, original perspectives for understanding the politics of contemporary Europe in two related but separate parts, or as the author puts it, 'interconnected essays'. The first part makes a comprehensive interpretation of the EU's political community, while the second examines the relationship between Central Europe and the European Union. Although the author outlines the diverse disciplinary foundations of the volume right at the beginning of the book, adding that these all are viewed through the lens of a former politician, ${ }^{2}$ the genre of the book frequently shifts from paragraphs and subchapters written by an academic scholar with a background in political theory, nationhood, identity theory and theories of power, ${ }^{3}$ to others that contain more practical insights and normative judgements of a politician, but in less theoretical depth. This does not detract from its readability, and even makes reading of the volume more enjoyable, as we can better understand the author himself and his own, mostly Christian democrat opinion on European politics. As he indicates at the beginning, guided by the motto of the London School of Economics where he spent most of his academic career: 'rerum cognoscere causas', he seeks to learn the causes of the things, and is not afraid of drawing conclusions. ${ }^{4}$ This self-assuredness is clear from this volume.

In the first part, the author uses the Greek term polis to describe the European political community, encompassing all the components of identity, common narratives, myths and habits of the community but also including other elements of the 'ecosystem' such as the EU institutions, member states, elites, lobbyists and civil society activists in the broadest sense. ${ }^{5}$ Therefore, although this work also raises the important question of what the EU really is, ${ }^{6}$ noting that it is not a monarchy, not a republic, neither a federation nor a confederation, not a commonwealth, not a protectorate and obviously not a state, it provides a different answer to this question than some of the leading contemporary political science/European studies literature ${ }^{7}$ on the subject, which mainly focus on analysing the operation of the political system through executive, legislative and judicial politics or on interpreting European governance. ${ }^{8}$ While Schöpflin acknowledges the 'sui generis

He served as a member of the European Parliament for Fidesz and of the Group of the European People's Party 2004-2019.

3 He has numerous renowned publications in these areas: George Schöpflin, Politics in Eastern Europe, 19451992 (Oxford: Blackwell, 1993); Stefano Bianchini and George Schöpflin, State Building in the Balkans. Dilemmas on the Eve of the 21st Century (Ravenna: Longo, 1998); George Schöpflin, Nations, Identity, Power (New York: New York University Press, 2000); George Schöpflin, Politics, Illusions, Fallacies (Tallin: Tallin University Press, 2012); George Schöpflin and Geoffrey Hosking (eds), Myths and Nationhood (New York: Routledge, 1997).

Schöpflin, The European Polis, 11.

Ibid. 15.

Ibid. 34 .

Simon Hix and Bjørn Høyland, The Political System of the European Union, 3rd edition (London: Bloomsbury Publishing, 2011); Neill Nugent, The Government and Politics of the European Union, 7th edition (Basingstoke: Palgrave Macmillan, 2010).

8 Hooghe, Liesbet, The European Commission and the Integration of Europe. Images of Governance (Cambridge: Cambridge University Press, 2001); Tanja A Börzel and Thomas Risse, 'When Europe Hits Home: Europeanization and Domestic Change', European Integration online Papers 4, no 15 (2000). 
nature' of the political community, for him it is an incomplete polis that is structured by asymmetries of power, with sovereignties voluntarily transferred to it by the member states with a weak to non-existent demos, resembling an empire that is mostly anti-national in character and pursuing a mission which is not explicitly but implicitly almost civilisational in nature ('ever closer union'). The first part provides a valuable analysis of the interactive relationship between law and politics, touching upon the concept of juristocracy. ${ }^{9}$ The first part also makes a brief summary and provides unique interpretations of the history of European integration, where the technocratic nature of integration, especially at the time of its launch after 1945 is highlighted, as well as the changes it underwent later in the process. In so doing, there is no reference to the shift from a 'permissive consensus'10 to the recent politicisation in the European political system or focus on the signs of 'constraining dissensus' ${ }^{11}$ that are widely referred topics in European studies literature. ${ }^{12}$ It would have been interesting to read his views on the possible positive side-effects of the current politicisation on the responsiveness to the public of the EU. The author argues that political innovation has slowed considerably in the last decade, particularly after the Lisbon Treaty entered into force, and while the European Union formerly aimed at conflict resolution and was dedicated to executing its soft power in a positive way, it 'has become conservative in the bad sense, of having become set in its ways, it has become slow to recognise contemporary realities, it has established definite truths for itself (like being post-national) and will not change. ${ }^{13}$ The European polis was gradually transformed into a punitive polis mainly due to the demands of left-wing political forces. ${ }^{14}$ Further reflecting on the punitive nature of the European polis, the author argues that the rule of law, as one of the European values listed in the Treaty (Article 2), was selected arbitrarily and 'weaponised' against some member states like Poland and Hungary. ${ }^{15}$

$9 \quad$ Béla Pokol, Juristocracy: Trends and Versions (Budapest: Századvég Kiadó, 2021).

10 Permissive consensus was the initial technocratic approach of launching European integration, which means that the European public passively approved the construction of integration, or at least did not actively reject it. Until the 1990s this was the defining logic of European integration. See Liesbet Hooghe and Gary Marks, 'A Postfunctionalist Theory of European Integration: From Permissive Consensus to Constraining Dissensus', British Journal of Political Science 39, no 1 (2009), 1-23.

11 Constraining dissensus is a recent concept used to describe the more politicised European integration where political-type debates occur more often. Although in terms of the development of the democratic nature of the EU, the public is essential but at the same time can make decision-making more difficult. Hooghe and Marks, 'A Postfunctionalist Theory'; Krisztina Arató and Boglárka Koller (eds), Az Európai Unió politikai rendszere (Budapest: Dialóg Campus, 2019).

12 See for example Pieter de Wilde, Anna Leupold and Henning Schmidtke (eds), The Differentiated Politicisation of European Governance (London - New York: Routledge, 2018).

13 Schöpflin, The European Polis, 23.

$14 \quad$ Ibid. 55.

15 Ibid. 70-87. It is worth noting here that the possibility of triggering the Article 7 procedure first came to light in relation to Austria in 1999 because of the ÖVP-FPÖ coalition and not due to the actions of (East) Central European members. 
At this point, the author narrows his focus and the analysis down to a single case, the recent turning point in Hungary's EU politics: the Sargentini Report ${ }^{16}$ which was passed by the European Parliament in 2018. The author criticises its voting mechanism, claiming that abstentions were not counted as votes cast and questions the legal basis of the rule of law mechanism as well as the content of the report. In the spirit of objectivity, the book includes long appendices with extracts from the related legal documents: ${ }^{17}$ the Sargentini Report and the Hungarian Government's official response to the Article 7 procedure before the Council..$^{18}$ Although the author's intention is understandable and legitimate, these appendices do not fit well with the genre of the essay and slightly disrupt the structure of the book. It would perhaps have been better to display and comparatively analyse some of the most important content elements in the main text and refrain from attaching long legal documents.

The second, shorter part of the volume examines Central Europe's experience in the European Union. The main argument of the author is that Central Europe is European, but 'differently European'. The shortcomings of the eastern enlargement, Central Europe's misadventure in the European Union and the unseen and unintended consequences of the 2004-2007-2011 waves of enlargement all contributed to the development of troubled relationship between the new members. Nevertheless, there are also historical reasons and certain identifiable trapfalls ${ }^{19}$ that contributed to the instability of Central Europe. Schöpflin assembles several valuable analytical propositions that can help to understand the uniqueness of the region, starting from its cultural traumas and ideological thinking, continuing with the hybridity of the region, before moving on to describe the emergence of a binary opposition in the post-enlargement period in the EU. As the author argues: 'The failure to offer Central Europe the affirmation of group worth was all the harder for Central Europeans to swallow, given their aspirations for a 'return to Europe'.20 An interpretation of the longue durée of Central European history - which is an abbreviated extract of Schöpflin's earlier work ${ }^{21}$ - can also be found in this part. The author argues that the region has a unique set of historical experiences that create specific thought styles and thought words. ${ }^{22}$ He claims: 'Where Central Europe differs from France, say, is that it never underwent the experience of a strong, centralised political power that could condense cultural meanings sufficiently for it to become national. ${ }^{23}$ Later in the volume,

16 Report on a proposal calling on the Council to determine, pursuant to Article 7(1) of the Treaty on European Union, the existence of a clear risk of a serious breach by Hungary of the values on which the Union is founded [2017/2131(INL)]. Committee on Civil Liberties, Justice and Home Affairs. Rapporteur: Judith Sargentini. European Parliament. A8-0250/2018.

17 Schöpflin, The European Polis, 93-137.

18 Information Note to the General Affairs Council of the European Union by the Hungarian Government on the Resolution on Hungary adopted by the European Parliament on 12th of September 2018.

19 Elemér Hankiss, Társadalmi csapdák. Diagnózisok (Budapest: Magvető, 1985).

20 Schöpflin, The European Polis, 148.

21 George Schöpflin, The Dilemmas of Identity (Tallinn: Tallin University Press, 2010).

22 Schöpflin, The European Polis, 156.

23 Ibid. 153. 
the mutual misunderstandings and misperceptions of the West and Central Europe are assessed, taking into account the role of the post-communist new elites, the questionable universality of liberalism, the absence of colonial guilt in Central Europe, the middleincome trap of the region and other potential pitfalls.

Both essays end with honest and personal, or as he claims 'incomplete' thoughts, where the author seeks to provide guidance for understanding contemporary processes rather than to articulate absolute truths. His analysis ends with his mandate in the European Parliament in 2019, but he is aware that new developments such as the launch of the Rule of Law Review Cycle or new occurrences might affect the arguments he made.

Overall, Schöpflin's latest book is a sophistically written monograph with a strong Central European, and within that Hungarian focus combining theoretical and practical aspects, which will make it a valuable contribution to the literature of multidisciplinary European Studies. 


\section{REFERENCES}

1. Arató, Krisztina and Boglárka Koller (eds), Az Európai Unió politikai rendszere. Budapest: Dialóg Campus, 2019.

2. Bianchini, Stefano and George Schöpflin (eds), State Building in the Balkans. Dilemmas on the Eve of the $21^{\text {st }}$ Century. Ravenna: Longo, 1998.

3. Börzel, Tanja A and Thomas Risse, 'When Europe Hits Home: Europeanization and Domestic Change'. European Integration online Papers 4, no 15 (2000).

4. De Wilde, Pieter, Anna Leupold and Henning Schmidtke (eds), The Differentiated Politicisation of European Governance. London - New York: Routledge, 2018.

5. Hankiss, Elemér, Társadalmi csapdák. Diagnózisok. Budapest: Magvető, 1985.

6. Hix, Simon and Bjørn Høyland, The Political System of the European Union, $3^{\text {rd }}$ edition. London: Bloomsbury Publishing, 2011.

7. Hooghe, Liesbet, The European Commission and the Integration of Europe. Images of Governance. Cambridge: Cambridge University Press, 2001. Online: https://doi. org/10.1017/CBO9780511491979

8. Hooghe, Liesbet and Gary Marks, 'A Postfunctionalist Theory of European Integration: From Permissive Consensus to Constraining Dissensus'. British Journal of Political Science 39, no 1 (2009), 1-23. Online: https://doi.org/10.1017/S0007123408000409

9. Information Note to the General Affairs Council of the European Union by the Hungarian Government on the Resolution on Hungary adopted by the European Parliament on $12^{\text {th }}$ of September 2018. Online: https://2015-2019.kormany.hu/ download/3/61/81000/The\%20official\%20legal\%20arguments\%20of\%20the $\% 20$ Hungarian\%20government\%20in\%20the\%20Article\%207\%20procedure\%20in\%20 the $\% 20$ European\%20Council\%20refuting\%20the\%20accusations\%20of\%20the $\% 20$ Sargentini-report.pdf\#!DocumentBrowse

10. Nugent, Neill, The Government and Politics of the European Union, $7^{\text {th }}$ edition. Basingstoke: Palgrave Macmillan, 2010.

11. Pokol, Béla, Juristocracy. Trends and Versions. Budapest: Századvég Kiadó, 2021.

12. Report on a proposal calling on the Council to determine, pursuant to Article 7(1) of the Treaty on European Union, the existence of a clear risk of a serious breach by Hungary of the values on which the Union is founded [2017/2131(INL)]. Committee on Civil Liberties, Justice and Home Affairs. Rapporteur: Judith Sargentini. European Parliament. A8-0250/2018. Online: www.europarl.europa.eu/doceo/document/A-82018-0250_EN.pdf

13. Schöpflin, George, Politics in Eastern Europe, 1945-1992. Oxford: Blackwell, 1993.

14. Schöpflin, George and Geoffrey Hosking (eds), Myths and Nationhood. New York: Routledge, 1997. Online: https://doi.org/10.4324/9781315022543

15. Schöpflin, George, Nations, Identity, Power. New York: New York University Press, 2000.

16. Schöpflin, George, The Dilemmas of Identity. Tallinn: Tallin University Press, 2010.

17. Schöpflin, George, Politics, Illusions, Fallacies. Tallin: Tallin University Press, 2012.

18. Schöpflin, George, The European Polis. Budapest: Ludovika University Press, 2021. 
Boglárka Koller (1974) is a Full Professor, researcher, Head of Department of European Studies at the University of Public Service - Ludovika. Her latest volume on the political economy of the Eurozone was published by Routledge UK in 2021 (Krisztina Arató, Boglárka Koller and Anita Pelle (eds), The Political Economy of the Eurozone in Central and Eastern Europe. Why In, Why Out? London: Routledge, 2021). She has more than twenty years' teaching experience in the area of European Studies at each level of education (BA, MA, PhD) in Hungary and worldwide. 